\title{
Improvement of nutritional and physicochemical proprieties of milk chocolates enriched with kale (Brassica olereacea var. acephala) and grape (Vitis vinífera)
}

\author{
Juliana Cajado Souza CARVALHO ${ }^{1 \star}$, Paulete ROMOFF², Suzana Caetano da Silva LANNES ${ }^{1}$
}

\begin{abstract}
Consumption of functional food has been growing recently, and products with healthier ingredients can influence the purchasing decisions. Studies have been shown that the development of chocolates with addition of functional ingredients can improve its nutritional properties. Considering it, the present study demonstrated that the addition of lyophilized kale and grape can modify physical, nutritional and physicochemical characteristics of the chocolates. The enriched milk chocolates showed higher values of dietary fibers and mineral content, which improved nutritional quality of the product when compared to plain milk chocolates. The results of the HPLC-DAD suggested the transference of phenolic compounds of kale and grape to the final enriched chocolates. The sensorial analysis indicated that differences among the formulated chocolates were indeed perceived and were well accepted. Thus, the addition of kale and grape in chocolates may be an alternative to improve the nutritional characteristics and the polyphenolic compound content in these chocolates.
\end{abstract}

Keywords: chocolate; fruits; vegetables; antioxidants.

Practical Application: The incorporation of fruits and vegetables in chocolate formulation has nutritional importance. The present study showed that addition of lyophilized kale and grape can modify the physical, nutritional and physical-chemical characteristics of the chocolates.

\section{Introduction}

The development of healthy formulations is a trend in the food market, according to "Brazil food trends 2020" (Madi et al., 2010). It involves products with lower caloric value, sugar content and trans fat, and more functional properties. Currently, consumers are looking for products which contribute to a healthy diet, with higher mineral and nutrient content and reduced values of fat and cholesterol.

Since past years, antioxidants have been in-depth explored due to their association with health benefits. It is known that the consumption of high amounts of different bioactive compounds is closely related to a lower risk of health disorders. The natural source of antioxidants includes a large number of vegetable and fruits (Oroian \& Escriche, 2015). Moreover, antioxidant activity is commonly correlated with functional proprieties as an alternative to reduce or avoid non-degenerative diseases and precocious aging (Oroian \& Escriche, 2015; Watson et al., 2013). For example, polyphenols are antioxidants that have promising chemical structures to prevent skin aging (Watson et al., 2013). Ali, Ismail, \& Kersten (2014) also related the presence of these compounds with prevention of metabolic diseases and obesity.

Cacao has been extensively studied for its intake health benefit as the improvement of vascular function (Pereira et al., 2014) cardiovascular prevention (Grassi et al., 2015) and cognitive functions (Sokolov et al., 2013). In 1999, Vinson, Proch, \& Zubik (Vinson et al., 1999) related the presence of the polyphenol content of cocoa to health benefits of chocolate due to differences in the polyphenol content in milk chocolate $(52.2 \pm 20.4 \mu \mathrm{mol} / \mathrm{g})$, when compared to dark chocolate $(126.0 \pm 17.4 \mu \mathrm{mol} / \mathrm{g})$, since there is a lower level of cocoa in milk chocolate. Pimentel et al. (2010) showed that the polyphenols in dark chocolate, with higher content of cocoa, are $21 \%$ higher than the dark chocolate with less cocoa content, which are $36 \%$ higher than milk chocolate and $55 \%$ higher than white chocolate.

Fruits and vegetables are also a very good sources of bioactive compounds, which can promote antioxidant actions in the body (Scalbert et al., 2005; Slavin \& Lloyd, 2012). It is known that the its consumption is correlated to reduced risk of breast cancer (Eliassen et al., 2012); prevent obesity and diabetes (Mozaffarian, 2016) and the increase of HDL cholesterol (Sarriá et al., 2015). Moreover, dried fruits are also known to provide bioactive compounds to maintain human health balance (Chang et al., 2016).

Kale is an important vegetable of the Mediterranean diet and it is known for its antimicrobial proprieties and capacity for disease prevention. In its composition, nine phenolic compounds with high antioxidant capacity were already described (Ayaz et al., 2008; Murador et al., 2016). Murador et al. (2016) founded high carotenoid content in raw kale, as well as high total phenolic content (29.16 mg GAE/100g raw sample). Mageney et al. (2017) described the phenolic compounds on Brassica oleracea and identify major components as flavonol kampoferol and quecetin 
Also with a high phenolic content, grape consumption is recommended to prevent non-degenerative diseases and precocious aging. Grapes are sources of antioxidants since it are mainly composed by anthocyanins, flavonoids and resveratrol (Xia et al., 2010).

Thus, this study aimed to increase the nutritional value of milk chocolate by adding freeze-dried kale and grape into the formula.

\section{Materials and methods}

\subsection{Lyophilization}

Kale samples were purchased in a local Market in São Paulo city, Brazil. The leaves were cleaned, sanitized and chopped for storage in ultrafreezer for 24 hours at $-88^{\circ} \mathrm{C}$.

Grapes also were purchased in a local market in São Paulo, Brasil. The variety of grape was Summer Royal without seed. Entire grapes were cleaned, sanitized and chopped for storage in ultrafreezer for 24 hours at $-88^{\circ} \mathrm{C}$.

For the lyophilization process the Edward's lyophilizer (Brazil) (Model: OS 3728) was used for 5 days. After that, kale leaves were crushed for 3 minutes in a termomixer Vorwerk (Brazil). The kale powder was stored in a desiccator to avoid humidity. Lyophilized grapes were cuted for reducing particle size and also stored in a dessicator.

\subsection{Production of chocolates}

Chocolates were produced in a Ball Mill Machine WA-FA20 (Mazzetti, Italy). The process time was 2 hours at $45^{\circ} \mathrm{C}$. Chocolate formulation included: cocoa liquor, cocoa butter, soy lecithin, sugar, vanilla, milk powder and lyophilized kale or grape. Process and formulation are described in Figure 1.

Tempering was carried out in a temper (Universal, Brazil) and the samples were stored in an incubator with controlled humidity $(60 \%)$ and temperature $\left(20^{\circ} \mathrm{C}\right)$.

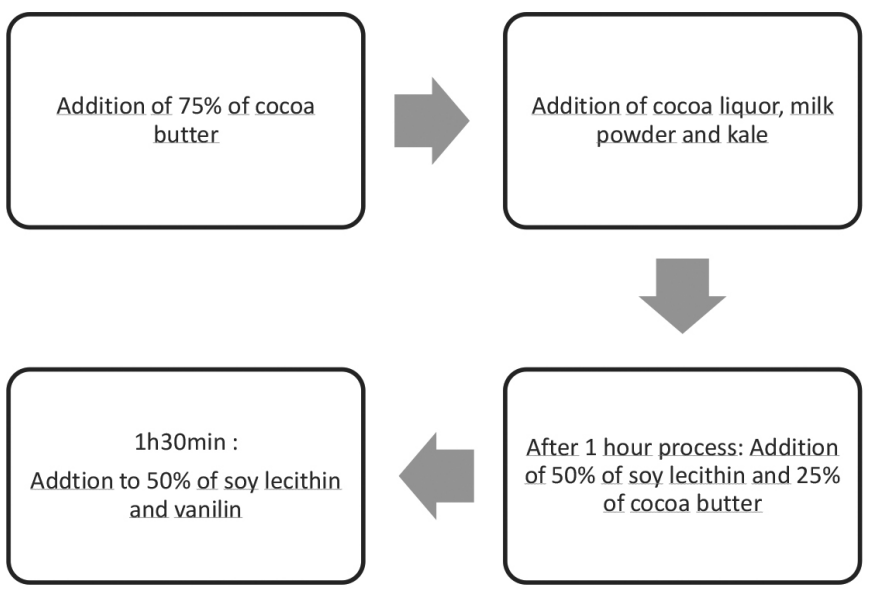

\subsection{Physicochemical evaluation}

The physicochemical evaluation of the chocolates was based on (AOAC, 2005) for ash, moisture, protein and fat content. All analysis were carried out in triplicate.

Water activity was measure in equipment Novasina, model Labmaster (Novasina, Switzerland) in triplicate.

\subsection{Texture, rheology and particle size}

Particle size of chocolates was analyzed by using the digital micrometer Digimatic number 293 (Mitutoyo, USA), with five repetitions.

Rheology analysis was conducted on a rotacional rheometer (Rheotest 3.1, German) with thermostatic bath at $40{ }^{\circ} \mathrm{C}$ and probe S1. A ramp with shear rate of $200 \mathrm{~s}^{-1}$ and time of $120 \mathrm{~s}$ were used. All the chocolate samples were analyzed in triplicate.

The texture was analyzed by using a texturometer TA-XT2 (Stable Micro Systems, United Kingdom). Fracture properties were tested with a probe $\mathrm{HDP} / 3 \mathrm{~PB}$ at $25^{\circ}$, in triplicate. Parameters were: Speed pre-test and post-test: $2.0 \mathrm{~mm} / \mathrm{s}$; distance: $10 \mathrm{~mm}$; charge cell: $25 \mathrm{~kg}$; Trigger Force: $0.05 \mathrm{~N}$; strength in compression - return to start. The data was collected by using the program "Texture Expert Exceed" - version 2.64 (Stable Micro Systems, United Kingdom), Sample: Chocolate bar with $9.0 \mathrm{~cm}$ x $2.5 \mathrm{~cm}$ x $1.3 \mathrm{~cm}$ (Lannes, 2008).

\section{Antiradical activity}

\subsection{Extraction}

The extraction method for all samples (chocolates, kale and grape) was conducted as suggested by (Genovese \& Lannes, 2009). A sample of ( $0.5 \mathrm{~g})$ was added to $20 \mathrm{~mL}$ of methanol $70 \%$, using an Ultraturrax mixer (Marconi, Brazil) for one minute in speed 4 , immersed in an ice bath. The extract was filtered through a paper filter and the resulting solution was stored in amber flask.

Figure 1. Schematic methodology of procedure on panel 1 and formulation on Panel 2, being A) Plain chocolate; B) chocolate with lyophilized kale C) chocolate with lyophilized grape. 


\subsection{Scavenging activity}

Scavenging activity against the DPPH and ABTS radicals were conducted as suggested by Oliveira et al. (2014)

Stock DPPH was prepared in methanol and its final concentration was determined spectrophotometricaly $(\varepsilon 515 \mathrm{~nm}=1.25 \times 104 \mathrm{~L} \mathrm{~mol}-1 \mathrm{~cm}-1)$. DPPH• stock solution was added to ethanol in a $10 \mathrm{~mm}$ absorbance quartz cell to final concentration of $80.0 \mu \mathrm{mol} \mathrm{L}-1$. The assay starts by adding the antiradical stock solution to a final volume of $3.0 \mathrm{~mL}$. The absorbance at $515 \mathrm{~nm}$ was monitored for 30 minutes.

An ABTS stock aqueous solution was prepared and stored at $4{ }^{\circ} \mathrm{C}$. For the oxidation of the ABTS $5 \mathrm{~mL}$ of the stock solution was used with $88 \mu \mathrm{L}$ of potassium persulfate with concentration of $1.4 \times 10-5 \mathrm{~mol} \mathrm{~L}^{-1}$, which reacted for 16 hours, protected from the light. Resulting concentration was measured with a UV visible Spectrophotometer at $734 \mathrm{~nm}$. ABTS•+ stock solution added to ethanol in a $10 \mathrm{~mm}$ absorbance quartz cell to a final concentration of $53.0 \mu \mathrm{mol} \mathrm{L}^{-1}$. Reaction starts with the addition of antiradical stock solution to final volum of $3.0 \mathrm{~mL}$. The absorbance at $734 \mathrm{~nm}$ was monitored for 30 minutes (Oliveira et al., 2014).

Trolox $^{\circledR}$ (6-hydroxy-2,5,7,8-tetramethylcroman-2-carboxilic acid) (Sigma-Aldrich) stock solution was prepared with $\mathrm{NaOH}$ $\left(0.01 \mathrm{~mol} \mathrm{~L}^{-1}\right)$ and ethanol.

All the reactions were monitored with a UV visible Spectrophotometer (Varian Cary 50 bio, USA) for 30 minutes and protected from the light.

The antiradical capacity was expressed in \% trolox, which indicates the correlation between linear concentrations of Trolox and other antiradical compounds. Trolox is known as an analogous of vitamin $\mathrm{E}$ and is considered a proportion of the antiradical capacity for scavenging against the free radical.

\subsection{HPLC-DAD}

The extract obtained was rota-evaporated using a BUCHI equipment (Switzerland) with temperature and control rotation, and dissolved in methanol at a proportion of $1 \mathrm{mg} / 1 \mathrm{~mL}$, and then processed in a SPE cartridge (Octadecyl C18/18\%). Analyses were made in duplicate in HPLC-DAD (Agilent Technology model 1200 Infinity, USA) in an $5 \mu \mathrm{m} \mathrm{C}_{18}$ Ascentis column (250x4.6mm (Supelco analytical, USA). The flow rate was of $1 \mathrm{~mL} / \mathrm{min}$ and the volume of injection was $40 \mu \mathrm{L}$. The wave-length was $260,280,320$ and $360 \mathrm{~nm}$.

For analysis of phenolic compounds the mobile phase used was: eluent A) acidified water with $2 \%$ of acetic acid, and B) Acetic acid 0.5\%: acetonitrile at a proportion of 50:50 (v/v). The gradient was: $0-20 \mathrm{~min} 10 \%$ of eluent B, $20-40 \mathrm{~min} 24 \%$ of eluent B, $40-60$ min $30 \%$ of eluent B, $60-65$ min $55 \%$ of eluent B, $65-70$ min $70 \%$ of eluent B, $70-75$ min $75 \%$ of eluent B and 75-80 100\% of eluent B (Silva \& Queiroz, 2016).

\subsection{Polyphenolic compounds}

The Folin-Ciocauteau method was used according to Singleton et al. (1999), with some modifications.

The standard curve was built with solutions of gallic acid $(50,100,150$ and $250 \mathrm{mg} / \mathrm{L})$. For the reaction $20 \mu \mathrm{L}$ of the extraction matter was used with $200 \mu \mathrm{L}$ of Folin-Ciocauteau reagent and mixed; after 5 minutes $750 \mu \mathrm{L}$ of sodium carbonate $20 \%$ was added and the volume was adjusted to $5 \mathrm{~mL}$. The solution remained protected from the light.

The measurements were carried out using a UV visible Spectrophotometer (Spectrum meter Brazil) at $760 \mathrm{~nm}$ and repeated in triplicate.

\subsection{Sensorial evaluation}

The global acceptance test (texture, taste, appearance) using the hedonic scale with 9 points and purchase intention with 5 points was applied on 90 untrained panelists of the University of São Paulo, after approval of University Ethics Committee $\left(n^{\circ} 1.393 .285\right)$.

Sensorial analyze was done in Sensorial Analysis Laboratory of Department of Biochemical-pharmaceutical Technology on Faculty of Pharmaceutical Science, in University of São Paulo.

Chocolates were prepared 24 hours before and storage at $20{ }^{\circ} \mathrm{C}$ with $60 \%$ of humidity, $5 \mathrm{~g}$ of samples were served in plastic plates, in monadic way, and panelists were advised to drink water between samples to avoid interferences.

\subsection{Data analyses}

All data analyses were carried out using with the software Statistica version 11 (StatSoft, EUA) for the Analysis of Variance (ANOVA) with a level of significance of $p<0,05$. The Tuckey's method were done to check for significant differences among the groups $(\alpha=95 \%)$.

\section{Results}

\subsection{Physicochemical analyses}

Considering the main constituents of chocolates (Afoakwa, 2010), the nutritional composition of plain milk chocolates and chocolates with addition of kale and grape were evaluated and the results are presented in Table 1.

Table 1 shows that the addition of kale and grapes does not modify significantly $(\mathrm{p}<0.05)$ the moisture content and water activity. Also, the evaluation of the sugar content shows that there is no difference between plain chocolate and the chocolate with grape, even when reducing the sugar content in the formulation, which indicates that the sugar in the formulation can be replaced by lyophilized fruits such as grapes.

On the other hand, the addition of kale and grape in chocolates modify some of the nutritional contents, comparing to plain milk chocolate. The addition of kale increases significantly $(\mathrm{p}<0.05)$ soluble fibers, while the addition of grape raised insoluble fiber levels. These results corroborate with the review published 
by Zhu et al. (2015) and with the USDA, which showed high levels of fibers in both grape and kale, respectively. Moreover, the enrichment of chocolate formulations with kale or grape have impacted the ash content (Table 1), causing a significant increase $(p<0,05)$ of this value.

\subsection{Rheology, texture and particle size}

The addition of natural products on the chocolate could modify quality characteristics, like rheology, which may become it undesirable for consumption. The results indicated that the addition of kale and grape modify this parameter without impacting the sensorial quality of this products.

The results of particle size, texture and rheological parameters can be found in Figure 1.

Chocolate with added grape shows an increase in particle size. Lyophilized grapes have high levels of sugar content which make them hygroscopic. For avoid humidity in chocolate samples, the grape were added after the process of production of chocolate. Thereafter, grapes did not pass throw refining stage, which can explain this increase in particle size. Despite desirable particle size of chocolate are between 20-30 $\mu \mathrm{m}$ (Afoakwa, 2010), sensorial analysis shows that the grape particles are desirable for some consumers.

The results show that there is a statistic difference $(\mathrm{p}<0.05)$ among all formulations related to particle size. The particle size is directly related to texture and yield values, and inversely related to Casson viscosity. Texture results indicated that the hardness of chocolate is modify with addition of grapes, with a statistic difference $(\mathrm{p}<0.05)$.

Rheology analysis reveal that plain milk chocolate shows the highest $(\mathrm{p}<0.05)$. Casson Viscosity, as well as the chocolate with added grape is the one with highest $(\mathrm{p}<0.05)$ yield value.

\subsection{Sensory Evaluation}

Sensorial analysis evaluated four parameters of all chocolate samples. The results for taste, texture and aspect are shown on Figure 2 and purchase intention on Figures 3 and 4.
Sensorial results showed that the difference in formulations affects the perception of consumers. The difference among chocolates were perceived by $92 \%$ of the panelists, which indicated that there were significant differences in sugar content, texture (of the chocolate with grape) and taste (among all chocolates). The chocolate with grape showed a higher variance in texture; $47.4 \%$ of the panelists indicated approval for "crunchy texture", while $52.6 \%$ of panelists disliked the product for the same reason.

In spite of these differences, all the chocolates were well accepted by consumers. This study showed a purchase intention of $61.1 \%$ for chocolate with kale, $66.6 \%$ for plain milk chocolate and $64.2 \%$ for chocolate with grape.

\subsection{Antiradical Profile}

The antiradical activity was evaluated by DPPH and ABTS method and the Folin Ciocauteau method was used to found the total phenolic content. The antiradical capacity is shown in Table 2 and Table 3.

The results of lyophilized kale and lyophilized grape show a high antiradical activity against DPPH radical, which corroborate with phenolic content analysis. Cocoa also show high antiradical activity and phenolic content. This results indicated that the raw materials were promising for increase antiradical capacity in chocolate.

The analysis of antiradical activity against the DPPH radical show that plain chocolate and that with added grape are statistically different $(\mathrm{p}<0.05)$, while the chocolate with kale shows no difference in comparison with the other two samples. This indicates that the scavenging activity against DPPH was not increased with the addition of kale and at the same time it decreased with the addition of grape. Nevertheless, the antiradical capacity is comparable to beverages and foods known as having high values of antiradical capacity, such as mango (211 mg trolox/100 g) and wine (196.4 mg Trolox/100 g) (Floegel et al., 2011; Vijaya Kumar Reddy et al., 2010).

The addition of kale and grape did not interfere with respect to the antiradical capacity of milk chocolate, since no significant difference $(p>0.05)$ among the samples was observed. Despite this, all the chocolates are considered as having high antiradical

Table 1. Nutritional composition of A) Plain Milk Chocolate, B) Milk chocolate with kale, C) Milk Chocolate with Grape. Different letters means statistic difference $(\mathrm{p}<0.05)$.

\begin{tabular}{lccc}
\hline & A & B & C \\
\hline Calories (kcal) & 564.68 & 554.68 & 555.7 \\
Moisture (g/100 g) & $1.73 \pm 0.48^{\mathrm{a}}$ & $2.07 \pm 0.29^{\mathrm{a}}$ & $2.27 \pm 0.25^{\mathrm{a}}$ \\
Water Activity (Aw) & $0.52 \pm 0.013^{\mathrm{a}}$ & $0.50 \pm 0.01^{\mathrm{a}}$ & $0.52 \pm 0.032^{\mathrm{a}}$ \\
Ash $(\mathrm{g} / 100 \mathrm{~g})$ & $2.53 \pm 0.14^{\mathrm{c}}$ & $2.68 \pm 0.054^{\mathrm{a}}$ & $2.57 \pm 0.027^{\mathrm{b}}$ \\
Protein $(\mathrm{g} / 100 \mathrm{~g})$ & $8.51 \pm 0.36^{\mathrm{a}}$ & $8.52 \pm 0.37^{\mathrm{a}}$ & $8.13 \pm 0.46^{\mathrm{a}}$ \\
Fat $(\mathrm{g} / 100 \mathrm{~g})$ & $36.26 \pm 0.39^{\mathrm{a}}$ & $35.06 \pm 0.38^{\mathrm{b}}$ & $35.50 \pm 0.87^{\mathrm{ab}}$ \\
Dietary Fibers Total $(\mathrm{g} / 100 \mathrm{~g})$ & 8.59 & 8.05 \\
Soluble Fibers $(\mathrm{g} / 100 \mathrm{~g})$ & 7.89 & 4.18 & 3.16 \\
Insoluble fibers $(\mathrm{g} / 100 \mathrm{~g})$ & 3.18 & 4.4 & 4.88 \\
Total sugar $(\mathrm{g} / 100 \mathrm{~g})$ & 4.71 & $17.00 \pm 0.0083$ & $21.00 \pm 0.015$ \\
Reduced sugars & $21.00 \pm 0.016$ & $7.82 \pm 0.029$ & $7.24 \pm 0.039$ \\
Non-reduced sugars $(\mathrm{g} / 100 \mathrm{~g})$ & $9.4 \pm 0.0032$ & 13.45 \\
\hline
\end{tabular}


1)

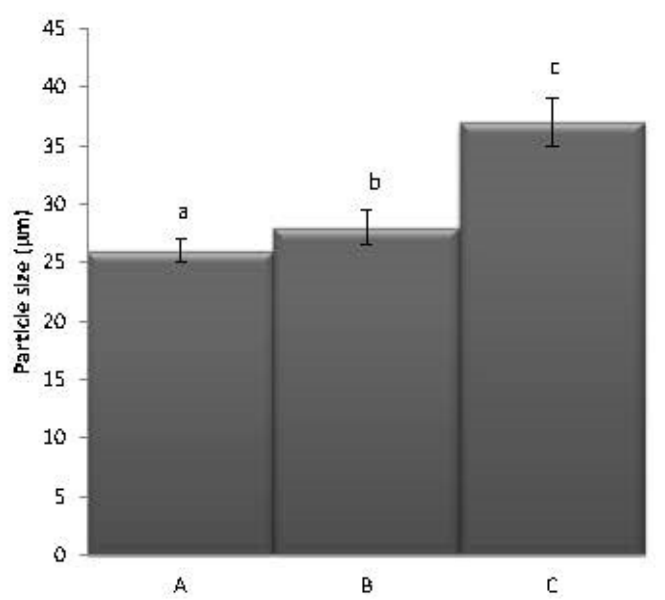

3)

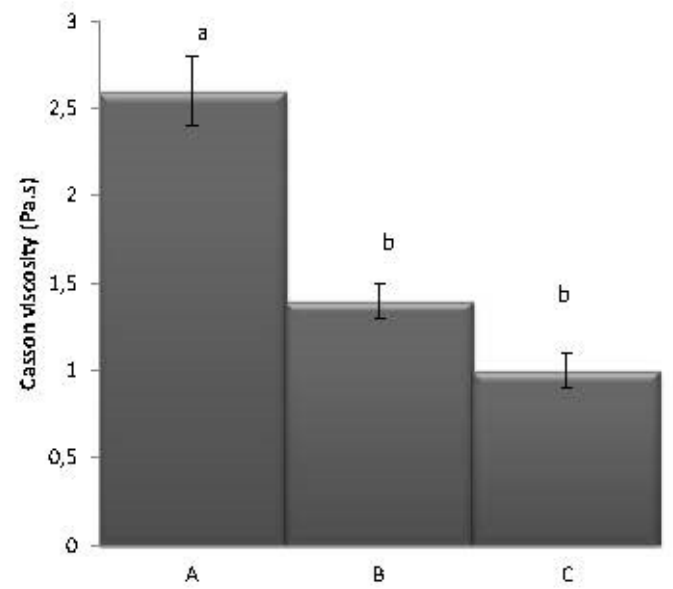

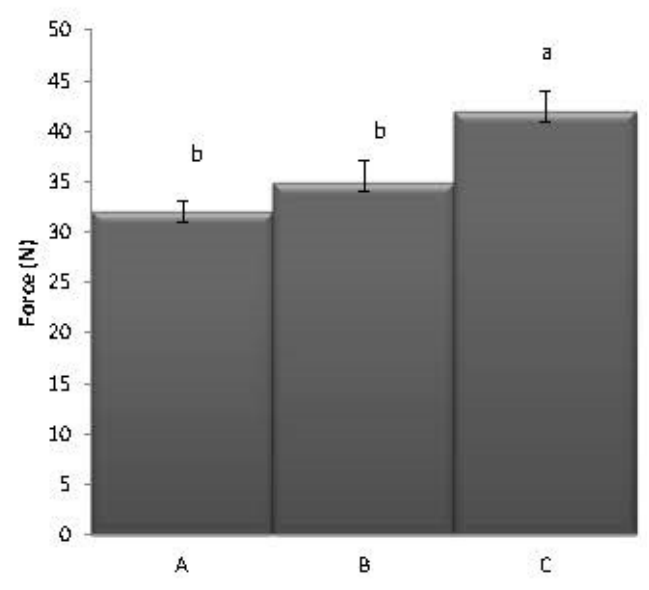

4)

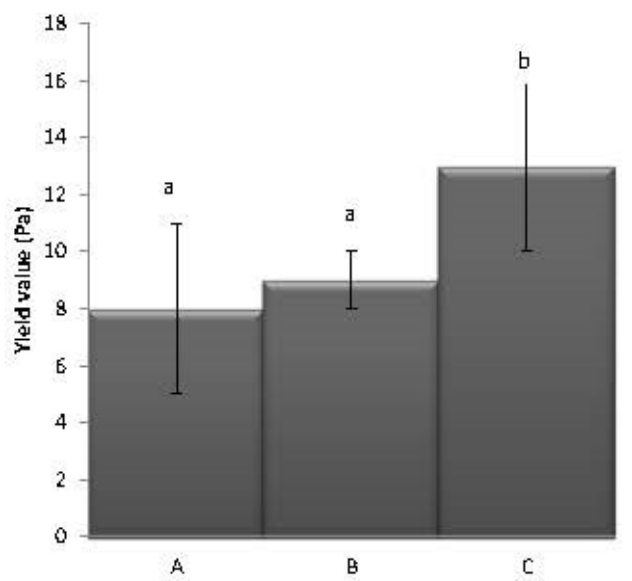

Figure 2. Results of (1) particle size, (2) Texture, (3) Casson Viscosity and (4) Yield Value for A) Milk chocolate B) Milk chocolate with added kale C) Milk chocolate with added grape. Different letters means statistic difference $(\mathrm{p}<0.05)$.

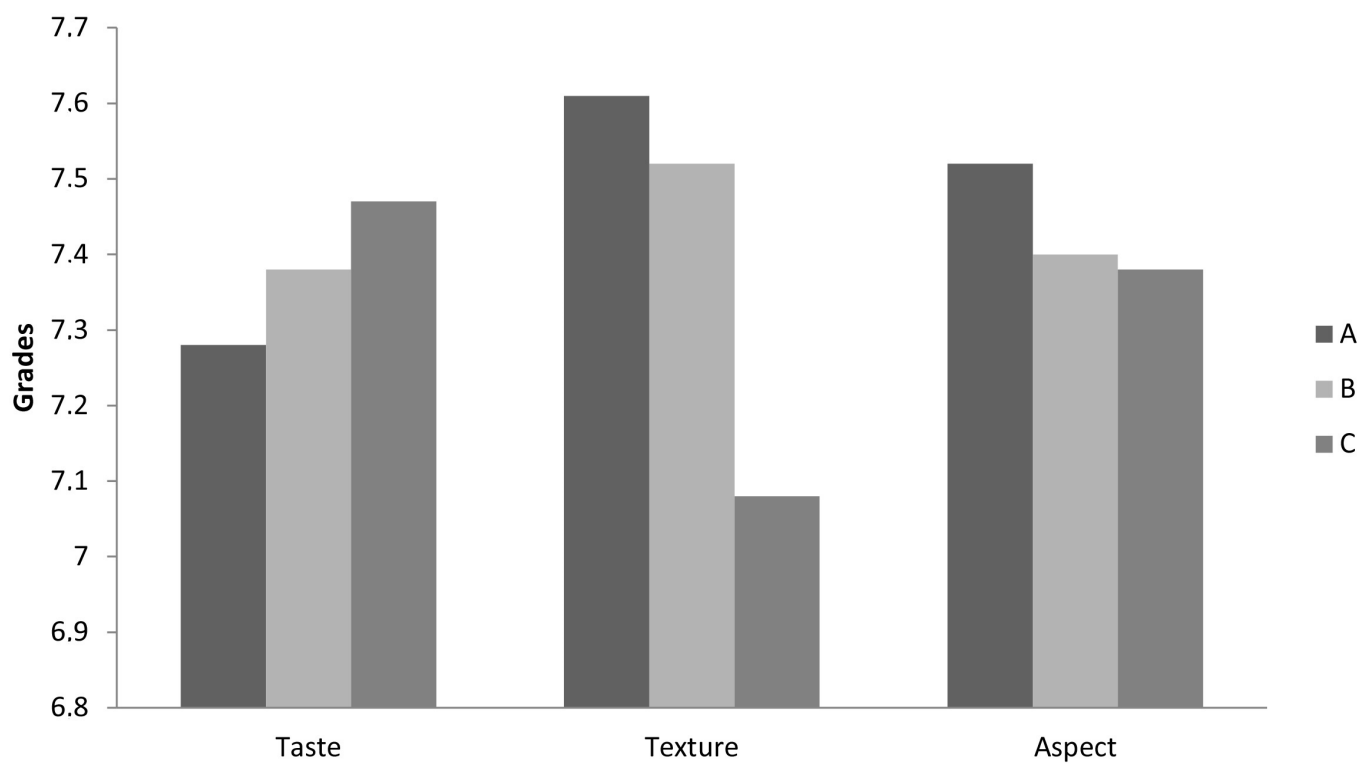

Figure 3. Sensorial evaluation results for 3 parameters: Taste, texture and aspect of A) Plain milk chocolate, B) Chocolate added kale C) Chocolate added grape. Values of means \pm SD for all samples. 
A

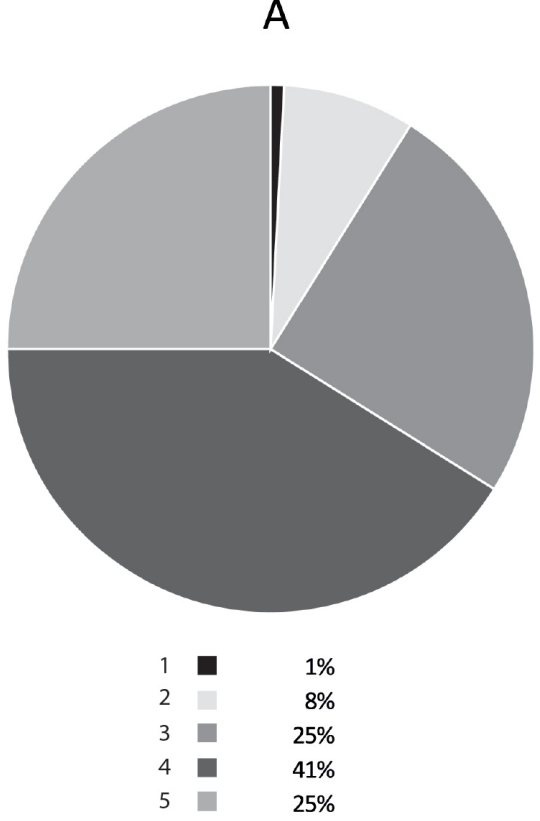

B

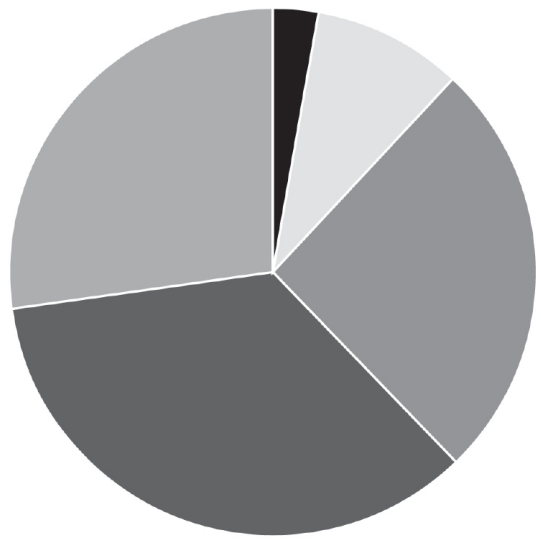

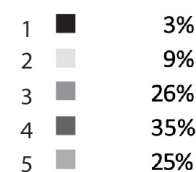

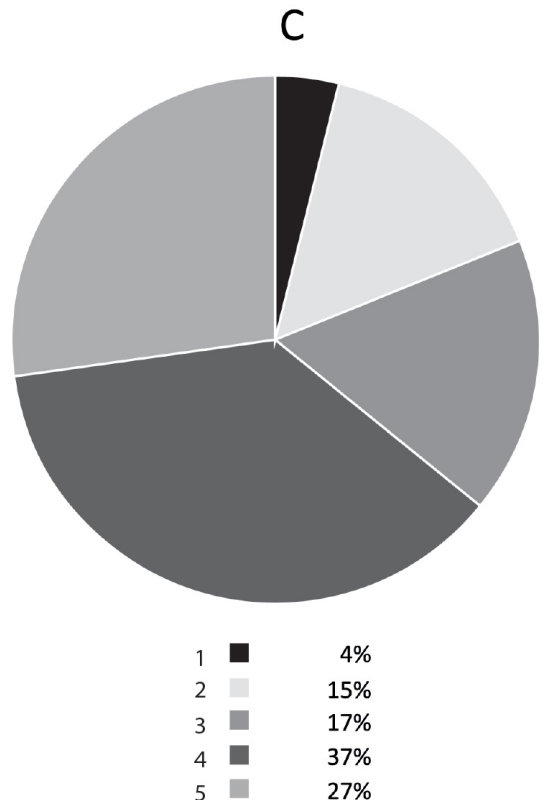

Figure 4. Purchase intention for A) Plain milk chocolate, B) Chocolate with added kale C) Chocolate with added grape.

Table 2. Results for antirradicalar activity against the DPPH radical phenolic content of lyophilized kale, lyophilized grape and cocoa liquor.

\begin{tabular}{ccc}
\hline & $\mathrm{mg} / \mathrm{gGAE}$ & $\mathrm{IC}_{50}(\mathrm{DPPH})(\mathrm{mg} / \mathrm{L})$ \\
\hline Lyophilized Kale & $226.16 \pm 5.13$ & $41.00 \pm 1.14$ \\
Lyophilized grape & $132.40 \pm 1.35$ & $66.45 \pm 0.97$ \\
Cocoa Liquor & $259.94 \pm 2.46$ & $2.91 \pm 0.012$ \\
\hline
\end{tabular}

Table 3. Results for antiradical activity against the DPPH radical, ABTS radical and phenolic content of A) Plain milk chocolate, B) Milk chocolate with added kale, and C) Milk chocolate with added grape.

\begin{tabular}{ccccc}
\hline & mg/gGAE & \%Trolox $($ DPPH $)$ & IC $_{50}(\mathrm{DPPH})(\mathbf{m g} / \mathrm{L})$ & \%Trolox $($ ABTS $)$ \\
\hline A & $74.22 \pm 4.10^{\mathrm{a}}$ & $278.75 \pm 3.98^{\mathrm{a}}$ & $6.82 \pm 0.14^{\mathrm{a}}$ & $443.97 \pm 4.12^{\mathrm{a}}$ \\
B & $74.29 \pm 3.93^{\mathrm{a}}$ & $250.93 \pm 7.29^{\mathrm{ab}}$ & $6.30 \pm 0.56^{\mathrm{a}}$ & $442.28 \pm 18.20^{\mathrm{a}}$ \\
C & $147.28 \pm 14.17^{\mathrm{b}}$ & $240.47 \pm 11.51^{\mathrm{b}}$ & $6.92 \pm 0.48^{\mathrm{a}}$ & $373.80 \pm 1.36^{\mathrm{a}}$ \\
\hline
\end{tabular}

capacity and can be compared with other fruits that are known for this propriety, such as blueberry (476.6 mg Vitamin C equivalent (VCE)/100 g), black plum (37 2mg VCE/100 g) (Floegel et al., 2011) and guava (496 mg Trolox/100 g) (Vijaya Kumar Reddy et al., 2010)

The statistical analysis of quantification of polyphenolic compounds shows that there was no significance difference ( $p>0.05$ ) between the milk chocolate and the chocolate with kale. However, when comparing the grape chocolate with the control, the study shows that there has been an increase of $50.44 \%$ in its value. This shows that the addition of kale did not modify the polyphenolic content and that the addition of grape did increase this content. However, the polyphenolic content of chocolate with kale and of plain chocolate are still high, being comparable to oranges (70 mg GAE/g) (Vijaya Kumar Reddy et al., 2010).

To confirm this hypothesis, the profile of phenolic compounds was carried out by HPLC-DAD (Figure 5).

The chromatogram analysis of milk chocolate with added kale, plain milk chocolate and lyophilized kale, shows that some compounds in lyophilized kale were transferred to the chocolate with added kale. The chromatograms of milk chocolate with added grape, plain milk chocolate and lyophilized grape show also that some of the grape peaks are transferred to the chocolate with added kale. Most of these compounds were previously identified in kale and grape which indicates that some of these compounds were transferred to the chocolates. 
A)

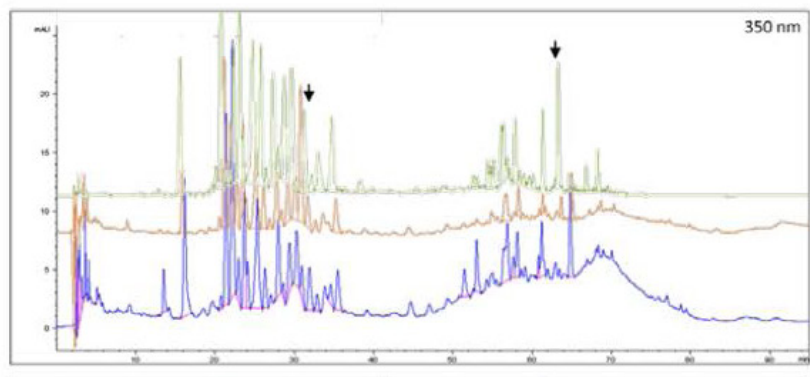

B)

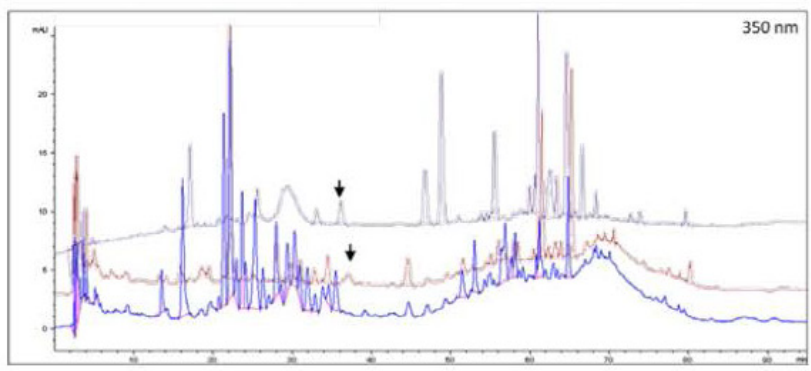

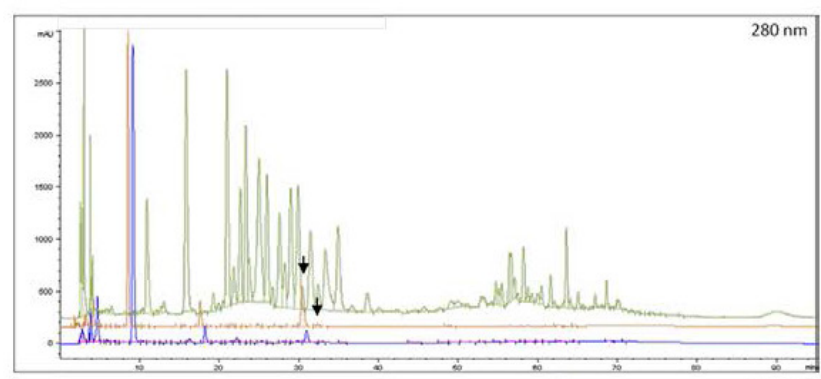

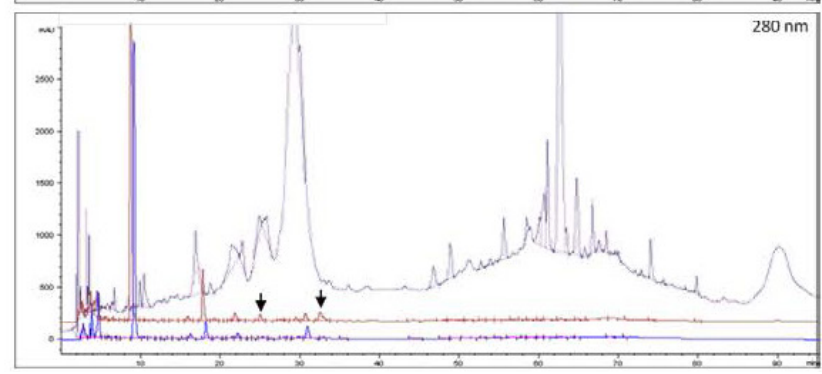

Figure 5. Chromatography profiles of A- plain chocolate (blue), kale (green), grape (purple) and chocolate with kale addition (orange) on C-18 reverse phase chromarography with detection at $280 \mathrm{~nm}$. The arrows demonstrate the peaks correspondent to enrichment by kale or grape into the chocolate with additions of these two ingredients. B- plain chocolate (blue), grape (green), grape (purple) and chocolate with kale addition (orange) on C-18 reverse phase chromatography with detection at $350 \mathrm{~nm}$ The arrows demonstrate the peaks correspondent to enrichment by kale or grape into the chocolate with additions of these two ingredients.

\section{Discussion}

The addition of lyophilized products aimed to improve the functional proprieties of chocolate and we showed here that it was able to modify some physicochemical characteristics of milk chocolate. The nutritional facts obtained here are similar to the values found by Afoakwa (2010) and some Brazilian national brands of milk chocolates. A low content of proteins was found for Afoakwa (2010) chocolate, $7 \mathrm{~g} / 100 \mathrm{~g}$, and also for three Brazilian brands (brand A- $6.8 \mathrm{~g} / 100 \mathrm{~g}$, brand B- $7.2 \mathrm{~g} / 100 \mathrm{~g}$ and brand C- $6.5 \mathrm{~g} / 100 \mathrm{~g}$ ). Moreover, all the chocolates produced here had a higher lipid content than that of the Afoakwa (2010) study (33 g/100 g) and two of the Brazilian brands (Brand A-32.4 g/100 g, and Brand C- $32.5 \mathrm{~g} / 100 \mathrm{~g}$ ). Brand B showed higher lipid content then the chocolates of this present study (38.4\%).

Mineral nutrients are essential for human health, helping vital cells, enzyme activation, hormonal secretion and better vitamin absorption. Elements like manganese, zinc and iron are important in the diet and improve the production of myoglobin and hemoglobin. The deficiency of iron affects a large part of the world population, so its supplementation is important (Gupta \& Gupta, 2014). Here we demonstrate that the chocolate with kale that has added mineral content. According to Ayaz et al. (2006) kale has a high level of micronutrients like iron $\left(72.6 \mu \mathrm{g} \mathrm{g}^{-1}\right)$, manganese $\left(53.5 \mu \mathrm{g} \mathrm{g}^{-1}\right)$, zinc $\left(9.4 \mu \mathrm{g} \mathrm{g}^{-1}\right)$, calcium $\left(19.7 \mu \mathrm{g} \mathrm{g}^{-1}\right)$ and potassium $\left(13.5 \mu \mathrm{g} \mathrm{g}^{-1}\right)$, which may explain why an increase of $8.6 \%$ of ash was found in the chocolate with this addition.

Results found in DPPH and ABTS assays indicated high profile of all produced chocolates as scavenging free radicals. The differences between these two parameters can be explain by reactivity of the two reagents used- DPPH radical reacts with more reactive antiradicals as the same as ABTS radical reacts with intermediary antiradicals (Oliveira et al., 2014). In spite of that, the results in this work also found that the addition of kale and grape, in this conditions, could not improve the antiradical activity of milk chocolate, which may can be explain by the interaction between proteins and polyphenolics. In fact, the difficulty to improve the antioxidant characteristics of chocolate with addition of fruits has been shown by other authors (Todorovic et al., 2015) rated the polyphenolic profile of milk and dark chocolates produced in Serbia with addition of raspberry. Although no statistic difference between plain dark chocolate and dark chocolate with addition of raspberry, it was found that the antiradical activity against DPPH and ABTS radicals increase with the addition of raspberry. Belščak-Cvitanović et al. (2012) studies the addition of leaves of raspberry (Rubus ideaus $L$.) aimed to increase phenolic compounds on milk and dark chocolate. Despite of the addition of lyophilized extract in all samples, the antiradical capacity as well as the polyphenolic content didn't increase. It was proposed that sugar and milk interacts with catechins, resulting in lower values of antiradicalar activity.

Siebert (1999) studied the interaction between proteins and polyphenolic compounds. It is known that the benzene ring and the hydroxylic groups of phenolic compounds can interact with the amine or carboxyl groups of proteins. These bonds create a web that modifies the bioavailability of polyphenolic compounds. Arts et al. (2002) showed that the addition of proteins (casein) in tea, alters its antiradical capacity, resulting in a false result. Jakobek (2015) reviewed the interaction between the polyphenolic compounds with lipids, proteins and carbohydrates. According to the author, these interactions can alter the bioavailability and bio-accessibility of these compounds in the body. Jakobek (2015) explains that the phenolic compounds with high quantities 
of hydroxyl groups and with high molecular weight, have the propensity to bind with the proteins. The phenolic compounds present in grape and kale have these chemical characteristics, which may explain the results obtained.

On the other hand, HPLC-DAD results show that some of the compounds present on kale and grape were might transfer to the enriched chocolates. When comparing the control chocolate with the chocolate with kale it is possible to perceive that there are some compounds added. The chromatography suggest the presence of derivate of benzoic acid and cynnamic acid in the chocolate with kale. Ayaz et al. (2008) identify the major phenolic compounds on kale as galic acid, vanilic acid, caffeic acid, ferulic acid, cummaric acid and sinapic acid, which are classified as hydroxycynamic acids and hydroxybenzoic acids. This study corroborates with the data found in the present work, which may explain the addition of these phenolic compounds on chocolate.

It was also observed the transfer of some components from grape to enriched-grape chocolate. Chromatography profiles suggest that these compounds are derivate of cinnamic acid, syringic acid and catequins. Several studies indicated the presence of phenolic compounds in grapes- Liang et al. (2012) found 36 phenolic compounds distributed in classes of anthocyanins, flavonols, hydroxycinamic acid, hydroxybenzoic acids and flavonoides. Ferreira et al. (2016) identify 24 polyphenols on mutant cultivar of Vitis vinifera which are manly phenolic acids, flavonols, stilbenes and anthocyanins. da Silva Padilha et al. (2017) found 20 phenolic compounds on Vitis vinifera and identify as major components syringic acid, peonidin, coumaric acid, catequins and epigallocatequins. Whereas this results, it is possible that some of these compounds are added to chocolate.

Catechins are mainly antioxidants of tea and they are associated with lower risk of chronic diseases, as well as the potential of inhibiting cancer cells and reducing the aging process (Braicu et al., 2013). Flavonols are also found in tea and have a high potential for reducing lipid peroxidation, acting as a cardiovascular protector (Heim et al., 2002), Hydrocynamic acids are studied for their antioxidant capacities, mainly because of their high bioactivity (Razzaghi-Asl et al., 2013) as well as hydroxybenzoic acids (Sevgi et al., 2015; Zhang et al., 2015).

We also evaluated physical proprieties of the enriched chocolates. Chocolate is described as a suspension of particles of sugar, milk and cocoa, disperse in cocoa butter. It is considering a non-Newtonian fluid, which means that the shear stress is not proportional to shear rate. Rheology determination of chocolates shows that this type of material has the characteristic to have yield stress and plastic viscosity. As well, it is known that the best way to describe rheological characteristics of chocolates is by the Casson model (Afoakwa et al., 2007; Lannes, 2008), which is adopted by OICC (Office International of Cocoa and Chocolate). The determination of rheological parameters of chocolate, particle size and texture are essential to quality control of these products, mainly because it have an effect on sensorial qualities (Afoakwa, 2010). Particle size higher than $30 \mu \mathrm{m}$ impact on a gritty texture, as well as particles size next to $20 \mu \mathrm{m}$ shows an soft texture and creamy mass (Afoakwa, 2010). Shear rate is related to processing of chocolate, as well as molding and coating and influence its structural and physical quality (Toker et al., 2016)

Low moisture in chocolate is an important factor of quality, whereas high values of moisture can cause sugar bloom, a defect that can occur during the shelf life of the product, modifying its characteristics of appearance and brightness (Afoakwa, 2010). Moreover, flow characteristics are also affected by the presence of moisture. Studies have shown that values above 3\% of moisture can cause an increase of initial tension and viscosity (Afoakwa et al., 2007). The moisture content found for all three chocolates shows that this important quality characteristic is preserved with the addition of lyophilized fruit and leaves.

Fat content and moisture are modifiers of the characteristics structure of chocolate. Afoakwa (2010) identified that higher fat contents and lower particle size affected the firmness, consistency, cohesiveness and viscosity of chocolates. The hardness is related to the fat content and the type of fat used in the formulation. This can explain the results of hardness obtained in this study. The highest fat content (35\%) found in these chocolates could result in higher hardness values. In addition, high fat content can reduce yield value and viscosity, which can also be noticed in this present study.

Rheology can also be affected by particle size characteristics - as texture. As Beckett (2011) reported, distribution of particles in chocolate influences viscosity; the higher the particle size, the lower the viscosity. Toker et al. (2016) show that the particle size is inversely related to yield stress and plastic viscosity and can affect the quality of the chocolates. The finds in the present study corroborate with this, since formulation $\mathrm{A}$ has the lowest particle size and a higher viscosity, while formulation $\mathrm{C}$ has a higher particle size and lower viscosity. Beckett (2011) reported that the values for chocolate viscosity are between 1-20 Pa.s. Also, the viscosity and yield values are related to distribution of particle size. Lower particle size results in more interaction among the particles, increasing superficial area and resulting in better flow (Afoakwa, 2010; Beckett, 2011; Konar et al., 2014); this relation was confirmed in this present study. The sensory evaluation shows that this difference on rheology and texture does not impact on sensorial perception and suggested that the product can be marketable.

\section{Conclusion}

Based on the exposed, it was found that it is possible to aggregate functional properties to milk chocolate. The addition of kale increased fiber and mineral content, as well as the addition of grape modified the structural properties of milk chocolate. The antiradical profile suggested that there was no increase of antiradical capacity with the enrichment; however, the chromatography profile of the phenolic compounds demonstrated that some compounds were transferred to the chocolates after the addition.

\section{Acknowledgements}

We thank to CAPES (Coordenação de Pessoal de Aperfeiçoamento de Nível Superior) and the University of São Paulo (USP) for the support. We also thank Universidade 
Presbiteriana Mackenzie, Instituto de Química (IQ-USP), and Prof. Dr. Josef Wilhem Baader for all the support.

\section{References}

Afoakwa, E. O. (2010). Chocolate science and technology. New Jersey: John Wiley \& Sons. http://dx.doi.org/10.1002/9781444319880.

Afoakwa, E. O., Paterson, A., \& Fowler, M. (2007). Factors influencing rheological and textural qualities in chocolate-a review. Trends in Food Science \& Technology, 18(6), 290-298. http://dx.doi.org/10.1016/j. tifs.2007.02.002.

Ali, F., Ismail, A., \& Kersten, S. (2014). Molecular mechanisms underlying the potential antiobesity-related diseases effect of cocoa polyphenols. Molecular Nutrition \& Food Research, 58(1), 33-48. http://dx.doi. org/10.1002/mnfr.201300277. PMid:24259381.

Arts, M. J., Haenen, G. R., Wilms, L. C., Beetstra, S. A., Heijnen, C. G., Voss, H.-P., \& Bast, A. (2002). Interactions between flavonoids and proteins: effect on the total antioxidant capacity. Journal of Agricultural and Food Chemistry, 50(5), 1184-1187. http://dx.doi. org/10.1021/jf010855a. PMid:11853501.

Association of Official Analytical Chemists - AOAC. (2005). Official methods of analysis (18th ed.). Maryland: AOAC.

Ayaz, F. A., Glew, R. H., Millson, M., Huang, H., Chuang, L., Sanz, C., \& Hayırloglu-Ayaz, S. (2006). Nutrient contents of kale (Brassica oleraceae L. var. acephala DC.). Food Chemistry, 96(4), 572-579. http://dx.doi.org/10.1016/j.foodchem.2005.03.011.

Ayaz, F. A., Hayırlıglu-Ayaz, S., Alpay-Karaoglu, S., Grúz, J., Valentová, K., Ulrichová, J., \& Strnad, M. (2008). Phenolic acid contents of kale (Brassica oleraceae L. var. acephala DC.) extracts and their antioxidant and antibacterial activities. Food Chemistry, 107(1), 19-25. http://dx.doi.org/10.1016/j.foodchem.2007.07.003.

Beckett, S. T. (2011). Industrial chocolate manufacture and use. New Jersey: John Wiley \& Sons.

Belščak-Cvitanović, A., Komes, D., Benković, M., Karlović, S., Hečimović, I., Ježek, D., \& Bauman, I. (2012). Innovative formulations of chocolates enriched with plant polyphenols from Rubus idaeus L. leaves and characterization of their physical, bioactive and sensory properties. Food Research International, 48(2), 820-830. http://dx.doi. org/10.1016/j.foodres.2012.06.023.

Braicu, C., Ladomery, M. R., Chedea, V. S., Irimie, A., \& Berindan-Neagoe, I. (2013). The relationship between the structure and biological actions of green tea catechins. Food Chemistry, 141(3), 3282-3289. http://dx.doi.org/10.1016/j.foodchem.2013.05.122. PMid:23871088.

Chang, S. K., Alasalvar, C., \& Shahidi, F. (2016). Review of dried fruits: Phytochemicals, antioxidant efficacies, and health benefits. Journal of Functional Foods, 21, 113-132. http://dx.doi.org/10.1016/j. jff.2015.11.034.

Eliassen, A. H., Hendrickson, S. J., Brinton, L. A., Buring, J. E., Campos, H., Dai, Q., Dorgan, J. F., Franke, A. A., Gao, Y. T., Goodman, M. T., Hallmans, G., Helzlsouer, K. J., Hoffman-Bolton, J., Hultén, K., Sesso, H. D., Sowell, A. L., Tamimi, R. M., Toniolo, P., Wilkens, L. R., Winkvist, A., Zeleniuch-Jacquotte, A., Zheng, W., \& Hankinson, S. E. (2012). Circulating carotenoids and risk of breast cancer: pooled analysis of eight prospective studies. Journal of the National Cancer Institute, 104(24), 1905-1916. http://dx.doi.org/10.1093/jnci/djs461. PMid:23221879.

Ferreira, V., Fernandes, F., Pinto-Carnide, O., Valentão, P., Falco, V., Martín, J. P., Ortiz, J. M., Arroyo-García, R., Andrade, P. B., \& Castro, I. (2016). Identification of Vitis vinifera L. grape berry skin color mutants and polyphenolic profile. Food Chemistry, 194, 117-127. http://dx.doi.org/10.1016/j.foodchem.2015.07.142. PMid:26471534.
Floegel, A., Chung, S.-J., von Ruesten, A., Yang, M., Chung, C. E., Song, W. O., Koo, S. I., Pischon, T., \& Chun, O. K. (2011). Antioxidant intake from diet and supplements and elevated serum C-reactive protein and plasma homocysteine concentrations in US adults: a cross-sectional study. Public Health Nutrition, 14(11), 2055-2064. http://dx.doi.org/10.1017/S1368980011000395. PMid:21414247.

Genovese, M. I., \& Lannes, S. C. S. (2009). Comparison of total phenolic content and antiradical capacity of powders and" chocolates" from cocoa and cupuassu. Food Science and Technology (Campinas), 29(4), 810-814. http://dx.doi.org/10.1590/S0101-20612009000400017.

Grassi, D., Desideri, G., Necozione, S., di Giosia, P., Barnabei, R., Allegaert, L., Bernaert, H., \& Ferri, C. (2015). Cocoa consumption dose-dependently improves flow-mediated dilation and arterial stiffness decreasing blood pressure in healthy individuals. Journal of Hypertension, 33(2), 294-303. http://dx.doi.org/10.1097/ HJH.0000000000000412. PMid:25380152.

Gupta, U., \& Gupta, S. (2014). Sources and deficiency diseases of mineral nutrients in human health and nutrition: a review. Pedosphere, 24(1), 13-38. http://dx.doi.org/10.1016/S1002-0160(13)60077-6.

Heim, K. E., Tagliaferro, A. R., \& Bobilya, D. J. (2002). Flavonoid antioxidants: chemistry, metabolism and structure-activity relationships. The Journal of Nutritional Biochemistry, 13(10), 572-584. http://dx.doi. org/10.1016/S0955-2863(02)00208-5. PMid:12550068.

Jakobek, L. (2015). Interactions of polyphenols with carbohydrates, lipids and proteins. Food Chemistry, 175, 556-567. http://dx.doi. org/10.1016/j.foodchem.2014.12.013. PMid:25577120.

Konar, N., Özhan, B., Artık, N., Dalabasmaz, S., \& Poyrazoglu, E. S. (2014). Rheological and physical properties of inulin-containing milk chocolate prepared at different process conditions. CYTA: Journal of Food, 12(1), 55-64. http://dx.doi.org/10.1080/1947633 7.2013.793214

Lannes, S. C. S. (2008). Cupuaçu: uma abordagem para sua utilização como substituto do cacao (Tese Livre docência). Universidade de São Paulo, São Paulo.

Liang, Z., Yang, Y., Cheng, L., \& Zhong, G. Y. (2012). Characterization of polyphenolic metabolites in the seeds of Vitis germplasm. Journal of Agricultural and Food Chemistry, 60(5), 1291-1299. http://dx.doi. org/10.1021/jf2046637. PMid:22229810.

Madi, L., Costa, A., \& Rego, R. (2010). Brasil Food Trends 2020. São Paulo: Gráfica Ideal.

Mageney, V., Neugart, S., \& Albach, D. C. (2017). A Guide to the Variability of Flavonoids in Brassica oleracea. Molecules (Basel, Switzerland), 22(2), 252. http://dx.doi.org/10.3390/molecules22020252. PMid:28208739.

Mozaffarian, D. (2016). Dietary and Policy Priorities for Cardiovascular Disease, Diabetes, and Obesity: A Comprehensive Review. Circulation, 133(2), 187-225. http://dx.doi.org/10.1161/ CIRCULATIONAHA.115.018585. PMid:26746178.

Murador, D. C., Mercadante, A. Z., \& de Rosso, V. V. (2016). Cooking techniques improve the levels of bioactive compounds and antioxidant activity in kale and red cabbage. Food Chemistry, 196, 1101-1107. http://dx.doi.org/10.1016/j.foodchem.2015.10.037. PMid:26593594.

Oliveira, S., Souza, G. A., Eckert, C. R., Silva, T. A., Sobral, E. S., Fávero, O. A., Ferreira, M. J. P., Romoff, P., \& Baader, W. J. (2014). Evaluation of antiradical assays used in determining the antioxidant capacity of pure compounds and plant extracts. Quimica Nova, 37(3), 497-503. http://dx.doi.org/10.5935/0100-4042.20140076.

Oroian, M., \& Escriche, I. (2015). Antioxidants: characterization, natural sources, extraction and analysis. Food Research International, 74, 1036. http://dx.doi.org/10.1016/j.foodres.2015.04.018. PMid:28411973. 
Padilha, C. V., Miskinis, G. A., Souza, M. E., Pereira, G. E., Oliveira, D., Bordignon-Luiz, M. T., \& Lima, M. D. (2017). Rapid determination of flavonoids and phenolic acids in grape juices and wines by RPHPLC/DAD: Method validation and characterization of commercial products of the new Brazilian varieties of grape. Food Chemistry, 228, 106-115. http://dx.doi.org/10.1016/j.foodchem.2017.01.137. PMid:28317702.

Pereira, T., Maldonado, J., Laranjeiro, M., Coutinho, R., Cardoso, E., Andrade, I., \& Conde, J. (2014). Central arterial hemodynamic effects of dark chocolate ingestion in young healthy people: a randomized and controlled trial. Cardiology Research and Practice, 7, 1-7. http:// dx.doi.org/10.1155/2014/945951. PMid:24982813.

Pimentel, F. A., Nitzke, J. A., Klipel, C. B., \& Jong, E. V. (2010). Chocolate and red wine: a comparison between flavonoids content. Food Chemistry, 120(1), 109-112. http://dx.doi.org/10.1016/j.foodchem.2009.09.078.

Razzaghi-Asl, N., Garrido, J., Khazraei, H., Borges, F., \& Firuzi, O. (2013). Antioxidant properties of hydroxycinnamic acids: a review of structure-activity relationships. Current Medicinal Chemistry, 20(36), 4436-4450. http://dx.doi.org/10.2174/0929867311320999 0141. PMid:23834166.

Sarriá, B., Martínez-López, S., Sierra-Cinos, J. L., Garcia-Diz, L., Goya, L., Mateos, R., \& Bravo, L. (2015). Effects of bioactive constituents in functional cocoa products on cardiovascular health in humans. Food Chemistry, 174, 214-218. http://dx.doi.org/10.1016/j. foodchem.2014.11.004. PMid:25529672.

Scalbert, A., Manach, C., Morand, C., Rémésy, C., \& Jiménez, L. (2005). Dietary polyphenols and the prevention of diseases. Critical Reviews in Food Science and Nutrition, 45(4), 287-306. http://dx.doi. org/10.1080/1040869059096. PMid:16047496.

Sevgi, K., Tepe, B., \& Sarikurkcu, C. (2015). Antioxidant and DNA damage protection potentials of selected phenolic acids. Food and Chemical Toxicology, 77, 12-21. http://dx.doi.org/10.1016/j. fct.2014.12.006. PMid:25542528.

Siebert, K. J. (1999). Effects of protein-polyphenol interactions on beverage haze, stabilization, and analysis. Journal of Agricultural and Food Chemistry, 47(2), 353-362. http://dx.doi.org/10.1021/ jf980703o. PMid:10563900.

Silva, L. R., \& Queiroz, M. (2016). Bioactive compounds of red grapes from Dão region (Portugal): Evaluation of phenolic and organic profile. Asian Pacific Journal of Tropical Biomedicine, 6(4), 315-321. http://dx.doi.org/10.1016/j.apjtb.2015.12.015.

Singleton, V., Orthofer, R., \& Lamuela-Raventós, R. (1999). Analysis of total phenols and other oxidation substrates and antioxidants by means of folinciocalteu reagent [en línea]. Methods in Enzymology, 299, 152-178.

Slavin, J. L., \& Lloyd, B. (2012). Health benefits of fruits and vegetables. Advances in Nutrition, 3(4), 506-516. http://dx.doi.org/10.3945/ an.112.002154. PMid:22797986.

Sokolov, A. N., Pavlova, M. A., Klosterhalfen, S., \& Enck, P. (2013). Chocolate and the brain: neurobiological impact of cocoa flavanols on cognition and behavior. Neuroscience and Biobehavioral Reviews, 37(10 Pt 2), 2445-2453. http://dx.doi.org/10.1016/j.neubiorev.2013.06.013. PMid:23810791.

Todorovic, V., Redovnikovic, I. R., Todorovic, Z., Jankovic, G., Dodevska, M., \& Sobajic, S. (2015). Polyphenols, methylxanthines, and antioxidant capacity of chocolates produced in Serbia. Journal of Food Composition and Analysis, 41, 137-143. http://dx.doi. org/10.1016/j.jfca.2015.01.018.

Toker, O. S., Sagdic, O., Şener, D., Konar, N., Zorlucan, T., \& Dağlıŏlu, O. (2016). The influence of particle size on some physicochemical, rheological and melting properties and volatile compound profile of compound chocolate and cocolin samples. European Food Research and Technology, 242(8), 1-14.

Vijaya Kumar Reddy, C., Sreeramulu, D., \& Raghunath, M. (2010). Antioxidant activity of fresh and dry fruits commonly consumed in India. Food Research International, 43(1), 285-288. http://dx.doi. org/10.1016/j.foodres.2009.10.006.

Vinson, J. A., Proch, J., \& Zubik, L. (1999). Phenol antioxidant quantity and quality in foods: cocoa, dark chocolate, and milk chocolate. Journal of Agricultural and Food Chemistry, 47(12), 4821-4824. http://dx.doi.org/10.1021/jf990312p. PMid:10606537.

Watson, R. R., Preedy, V. R., \& Zibadi, S. (2013). Polyphenols in human health and disease. New York: Academic Press.

Xia, E.-Q., Deng, G.-F., Guo, Y.-J., \& Li, H.-B. (2010). Biological activities of polyphenols from grapes. International Journal of Molecular Sciences, 11(2), 622-646. http://dx.doi.org/10.3390/ijms11020622. PMid:20386657.

Zhang, Y., Shen, Y., Zhu, Y., \& Xu, Z. (2015). Assessment of the correlations between reducing power, scavenging DPPH activity and anti-lipid-oxidation capability of phenolic antioxidants. Lebensmittel-Wissenschaft + Technologie, 63(1), 569-574. http:// dx.doi.org/10.1016/j.lwt.2015.03.047.

Zhu, F., Du, B., Zheng, L., \& Li, J. (2015). Advance on the bioactivity and potential applications of dietary fibre from grape pomace. Food Chemistry, 186, 207-212. http://dx.doi.org/10.1016/j. foodchem.2014.07.057. PMid:25976812. 